\title{
The Inner Dimension of the Orthodox Tradition and Traditionalism According to André Scrima's Hermeneutics*
}

\author{
BOGDAN TĂTARU-CAZABAN ${ }^{*}$
}

A unique figure in the Orthodox Church, André Scrima was a bridge-personality among Christians and between Christianity and other religions. In his early works, bearing witness to a "spiritual inheritance" and a "blessing of grace" that he had personally received, he stressed the inner dimension of Eastern Christianity represented by Hesychastic spirituality - a perennial divine inspiration manifested across history. But both as a spiritual figure and a professor of comparative religion, he oriented his reflection toward considering the religious plurality of the world from a Christian perspective. Searching for the "lieu théologal" of hospitality for others' spiritualities became one of the main purposes of Scrima's reflections which occasionally dealt in a sympathetic as well as critical manner with Traditionalism. This paper aims to highlight the interest raised by an Orthodox reflection on the so-called "esoteric" side of his Tradition which leads to a hermeneutic of religious diversity.

Keywords: Orthodoxy, Hesychasm, Traditionalism, Eastern spirituality, religious pluralism

Original, uncategorizable, mysterious, André Scrima (1925-2000) was an ecclesiastical figure with an unusual biography, a bridge-personality among Christians and between Christianity and other religions. He pursued his studies in philosophy, medicine and mathematics in the 40's, was part of a Hesychastic revival group at Antim Monastery and embraced a monastic life in the most terrifying years of communist oppression in Romania. However, being a monk allowed him an unexpected opportunity to leave for India in 1956 - the gate to so many marvellous encounters and achievements that he would realize with tenacity and discretion alike. Keen on Sanskrit ever since he was young, he spent his time in India writing a doctoral dissertation titled The Ultimate: its Methodological and Epistemological

\footnotetext{
* This is a revised version of the paper I presented at the EASR Conference in Bern, June 2018 (panel coordinated by Prof. Vasilios Makrides and Dr. Ionuț Daniel Băncilă). I would like to thank Dr. Ionuț Daniel Băncilă who prompted me to write on this subject and Dr. Dragos Ivana for his help in preparing the first English version of this article.

** Bogdan Tătaru-Cazaban, Institute for the History of Religions, Romanian Academy, Calea 13 septembrie nr. 13, București, sector 5, tatarucazaban@gmail.com, tatarucazaban@ ihr-acad.ro.
} 
Connotation according to Advaita-Vedanta, which, unfortunately, he was unable to complete. ${ }^{1}$ Before returning to Europe and becoming engaged in the ecumenical movement as a personal representative of the Patriarch Athenagoras at the third session of the Second Vatican Council, ${ }^{2}$ André Scrima had made his outstanding debut in 1958 with an extensive article, L'avènement philocalique dans l'Orthodoxie roumaine, ${ }^{3}$ published in the Istina review at the request of the Dominican Christophe Dumont, but discreetly signed as "un moine de l'Église Orthodoxe de Roumanie". The article was a testimony to the revived Hesychast tradition and The Philokalia in the circles he had frequented in Romania while a young intellectual monk, as well as a comprehensive analysis of the meaning of tradition in Eastern spirituality.

The interwoven themes of tradition, spiritual paternity, the prayer of the heart and contemplative knowledge formed the distinguishing characteristic of the academic persona of Father and Professor Scrima: from the celebrations devoted to the millennium of monastic presence on Mount Athos ${ }^{4}$ until he returned to Bucharest, where he published a special auto-

\footnotetext{
${ }^{1}$ See: Andrei Pleșu, "Introducere," in André Scrima, Timpul Rugului Aprins. Maestrul spiritual în tradiția răsăriteană, ed. Anca Manolescu (București, Humanitas: 1996, ${ }^{2} 2000$; references will be from now on on the second edition); Raimon Panikkar, "André Scrima. A personal recollection," in André Scrima. Expérience spirituelle et langage théologique. Actes du colloque de Rome, eds. Daniela Dumbravă and Bogdan Tătaru-Cazaban, OCA 306 (Roma, Edizioni Orientalia Christiana: 2019), 29-30. An outline of what it was supposed to be Scrima's doctoral thesis was published in Andrei Scrima, Antropologie apofatică, ed. Vlad Alexandrescu (București, Humanitas: 2008), 172-74. Scrima also mentioned his PhD project in a letter addressed in 1971 to Arion Roșu (CS 278, "André Scrima Archive", New Europe College, Bucharest).

2 See: A. Scrima, "Aperçu orthodoxe sur le sens oecuménique de l'Église," Lumen Vitae 20, no. 3 (1965): 495-503; idem, "Das zweite Vatikanum in orthodoxer Sicht," Una Sancta 20 (1965): 53-57; idem, "La Chiesa Ortodossa e l'attuale momento ecumenico," Russia cristiana 65-66 (1965-1966): 3-8, 3-9; idem, "La Constitution dogmatique Lumen Gentium: simples réflexions d'un Orthodoxe," in L'Église de Vatican II, Unam Sanctam 51C, eds. Thomas Camelot, Guilheme Barauna and Yves Congar, vol. 2 (Paris, Cerf: 1966), 1279-94; idem, "Orthodoxe und Katholiken. Ihre besondere Situation im Gespräch der christlichen Ökumene," Wort und Wahrheit 22, no. 2 (1967): 89-98; idem, "Révélation et tradition dans la Constitution dogmatique Dei Verbum selon un point de vue orthodoxe," in Vatican II, La Révélation divine, Unam Sanctam 70 B, ed. Bernard Dominique Dupuy, vol. 2 (Paris, Cerf: 1968), 523-39. For a synthesis on Scrima's ecumenical views, see: Tătaru-Cazaban and Miruna Tătaru-Cazaban, "L'Unité des chrétiens et son langage. Fragments d'un Journal orthodoxe du Concile Vatican II," in Dumbravă, Tătaru-Cazaban, André Scrima, 123-40.

${ }^{3}$ Scrima, "L'avènement philocalique dans l'Orthodoxie roumaine," Istina no. 3-4 (1958): 295-328, 443-75; Romanian trans. by Miruna Tătaru-Cazaban and Lucian Petrescu, in Scrima, Ortodoxia și încercarea comunismului, ed. Alexandrescu (București: Humanitas, 2008). ${ }^{4}$ Scrima, "Le millénaire monastique. La grande Laure de l'Athos 963-1963. Son sens, sa commémoration, sa portée œcuménique," Vers l'unité chrétienne 7-8 (juillet-octobre 1963):
} 
biography, Timpul Rugului Aprins. Maestrul spiritual în tradiția răsăriteană, ${ }^{5}$ which was actually his only anthumous book. Thus, throughout four decades, in different forms and on various occasions, André Scrima scrutinizes the theme of his life marked by the meeting with a spiritual master called John the Stranger (Ivan Kulîgyn) at Antim Monastery in Bucharest in the mid-40's. Father John descended from the Russian tradition, rooted in Paisy Velichkovsky's hesychastic renewal, and was a refugee from the Red Army. ${ }^{6}$ He transmitted "the blessing" for the prayer of the heart to the two masterminds of the Antim Monastery Burning Bush group and the young Scrima received, in his turn, this "initiation" from one of the two leaders. In this way, following a "calling", a "choice beyond nature", Scrima became part of a vivid spiritual tradition and was involved in a continuous process of self-discovery and meditation on contemplative life that underlies the itinerant condition of the stranger. ${ }^{7}$

The specific value of Scrima's contribution to the reflection on the meaning of the Eastern spiritual tradition stems from the fact that it is a meditation on one's own experience in a discourse which, on the one hand, reveals the most significant landmarks of tradition and, on the other, aims to objectivise itself, uses the tools employed by the comparative study of religions, and opens itself to religious "otherness". In this regard the annotations he made for a "spiritual anthropology" are very insightful, in which he pursues a comparative approach between different "meditative techniques", il-

49-57; idem, "Les Roumains et le Mont Athos," in Le Millénaire du Mont Athos, 963-1963. Études et mélanges, vol. 2 (Chevetogne, 1965), 146-52; idem, "Réflexions sur les rythmes et la fonction de la tradition athonite," in Le Millénaire du Mont Athos, 301-24.

${ }^{5}$ Scrima, Timpul Rugului Aprins, french trans. Anca Vasiliu, in Contacts 55, no. 203 (juillet 2003): 315-63; 56, no. 207 (juillet-septembre 2004): 265-302; L'accompagnamento spirituale. Il movimento del Roveto ardente e la rinascita esicasta in Romania, prefazione alla prima edizione di Andrei Pleșu, edizione italiana a cura di Adalberto Mainardi (Magnano, Qiqajon: 2018).

${ }^{6}$ Ionuț Băncilă, “André Scrima’s Elusive Master: Father John Stránnik,” in Dumbravă, TătaruCazaban, André Scrima, 227-40. See also: Radu Drăgan, "Une figure cu Christianisme oriental du vingtième siècle: Jean l'Etranger", Paper given at the 6th European Association for the Study of Religion Conference, Religious History of Europe and Asia, Bucharest, 21 September 2006, in Politica Hermetica 20 (2006): 124-142 (I don't share the author's "gnostic» interpretation on Scrima's hermeneutics of Tradition).

${ }^{7}$ Vasiliu, “André Scrima, l'étranger," Contacts 56, no. 207 (juillet-septembre 2004): 211-22 ; idem, "André Scrima: la vie philosophique d'un moine pèlerin contemporain (équivocité et paradoxe du témoignage)," in Vie philosophique et vies de philosophes, textes réunis et présentés par Bruno Clément et Christian Trottmann (Sens \& Tonka, Paris: 2010), 95-106; Manolescu, "André Scrima (1925-2000) ou la stabilitas in peregrinatione," Contacts 70, no. 261 (2018): 21-27; Alexandru Tofan, "Lexpérience religieuse comme itinérance. André Scrima et Michel de Certeau," Revue Roumaine de Philosophie 60, no. 2 (2016): 239-53. 
lustrated partially in his article published in Istina and most probably linked to his doctoral project ${ }^{8}$. Scrima is also the subject and object of his own texts, which initially he was not accustomed to signing, and to which he apparently had the calophilic attachment of a writer and the self-imposed detachment of someone who wanted to be distant to his own works.

The young Scrima arrived at Antim Monastery, the core of his spiritual life, as a result of the guidance offered by Professor Anton Dumitru (19051992) ${ }^{9}$, who taught the history of logic and metaphysics at the University of Bucharest. Anton Dumitru was also an avid reader and an adept of René Guénon's view of "the spiritual crisis of the modern world"10. Scrima acknowledged the role played by Professor Dumitriu in his youth, but he made it clear that his arrival at Antim was also the sign of a "separation" from the one who had been his mentor. One should not forget Marcel Avramescu (1909-1984), another supporter of Traditionalism in the 30's, who turned from being a surrealist poet to a priest. ${ }^{11}$ Scrima gratefully mentioned him in one of his last interviews. ${ }^{12}$ The autobiographical fragments we know fail to reveal whether the "traditionalist" readings were part of the influence Anton Dumitriu exerted on Scrima. Nevertheless, L'avènement philocalique, the first text published in the West, shows that Scrima was highly conversant with both René Guénon's and Frithjof Schuon's writings, as well as with Jacques-Albert Cuttat's study La rencontre des religions, avec une étude sur la spiritualité de l'Orient chrétien (1957) ${ }^{13}$. He chose to be explicitly critical in several notes and to make a sharp and ironical distinction between the Church spiritual tradition and esoteric Traditionalism:

\footnotetext{
${ }^{8}$ See: Scrima "Note la o antropologie eventuală," in Antropologie apofatică, 201.

${ }^{9}$ Scrima, Timpul, 103-4, n. 2.

${ }^{10}$ For a historical perspective on Traditionalism: Antoine Faivre, Western Esotericism: A Concise History, trans. Christine Rhone (Albany: State University of New York, 2010), 96-100; Mark Sedgwick, Against the Modern World. Traditionalism and the Secret Intellectual History of the Twentieth Century (Oxford: Oxford University Press, 2004). See also: René Guénon. L'appel à la sagesse primordiale, ed. Philippe Faure (Paris, Cerf: 2016), particularly Xavier Accart, "La réception de l'œuvre de René Guénon par les milieux littéraires et intellectuels de son temps"; Jean-Pierre Brach, "Christianisme et "Tradition primordiale» dans les articles de René Guénon pour la revue catholique Regnabit”; Patrick Ringgenberg, "De la Tradition primordiale à la Sophia perennis: les métamorphoses de l'universalisme de Guénon à Schuon"; Jérôme Rousse-Lacordaire o.p., "Pensée traditionnelle et théologie chrétienne des religions". ${ }^{11}$ He obtained his B.A. in Theology with a thesis on Qabbalah. Gnoza tradițională a Legii celei Vechi. See also: Constantina Buleu, "Marcel Avramescu and Interwar Romanian Esotericism," Transylvanian Review 21 (2012): 123-32.

${ }^{12}$ Roxana Sorescu, "Un autoportret, mai multe identități: Andrei Scrima,” Viața Românească no. 8-9 (2017) (http://www.viataromaneasca.eu/revista/arhiva), accessed June 16, 2020.

${ }^{13}$ See: Enrico Montanari, La fatica del cuore. Saggio sull'ascesi esicasta (Jaca Book, Milano: 2003), 129-32.
} 
On est, essentiellement, dans un autre univers que celui de la doctrine ésotérique protégeant, par une initiation secrète, sa «vérité universelle» contre les psychiques et les hyliques. La distinction, elle-même extérieure, entre ésotérique et exotérique, est dépourvue de sens ici, car il ne s'agit plus d'une continuation cachée et niant le temps, d'un passage sacré, mais d'une continuation de Présence, à chaque instant créatrice et vivifiante, - on dirait d'une contemporanéité de l'Esprit. Il nous semble opportun de discerner, dans ce sens, entre la tradition de l'Église et les autres formes traditionnelles, en cours de réanimation artificielle à l'heure actuelle. ${ }^{14}$

What was kept under cover or just hinted at in the extensive article published in Istina becomes an explicit topic, with additional nuances, in Scrima's 1994 Preface to the Romanian translation of Schuon's book, De l'unité transcendante des religions, ${ }^{15}$ and in the comments made in Timpul Rugului Aprins, in which he writes on what could be attributed to Guénon and, concurrently, on the distance towards the traditionalist interpretation of Hesychasm. ${ }^{16}$ All these anthumous elements of a "dossier" about Scrima's relationship with Traditionalism have been investigated by Enrico Montanari ${ }^{17}$ and by Marco Toti ${ }^{18}$ with reference to the then partial Italian translation of Timpul Rugului Aprins (Il padre spirituale).$^{19}$ In this article I shall pick up a few essential elements of this "dossier" so as to more finely delineate some conclusions drawn by those who have studied it before and particularly to consider them from the broader perspective offered by the texts published after Scrima's death.

\footnotetext{
${ }^{14}$ Scrima, "Lavènement," 300-1. Scrima's article does not focus only on Eastern Christian spirituality. He tries to underline his radical specificity on the ground of a comparative approach with other spiritual traditions, particularly with yoga (see the critique of A. Bloom's conciliant position, 453, n. 8: “...nous serions enclins de voir dans l'oraison hésychaste l'opposé polaire, l'opposé chrétien du yoga”). In Scrima's view the Hesychastic prayer should not be reduced to its spiritual technique: "la méthode spirituelle devient signe de l'ontologie nouvelle" (455). See also the critical commentary concerning Louis Gardet's article, "La mention du Nom divin dans la mystique musulmane" (ibidem, n. 13).

${ }^{15}$ Scrima, "Cuvînt înainte," in F. Schuon, Despre unitatea transcendentă a religiilor [De l'unité transcendante des religions] (Paris: Gallimard, 1948), trans. Manolescu (București: Humanitas, 1994), 5-18; reprint: André Scrima, Teme ecumenice, ed. Manolescu (București: Humanitas, 2004), 139-57 (references are made to the second edition).

${ }^{16}$ Scrima, Timpul, 49-50, 56-57.

${ }^{17}$ Montanari, La fatica, 116-44; a reviewed perspective in "Prospettive di una "gnosi viva": Andrei Scrima e l'Occidente," in Dumbravă, Tătaru-Cazaban, André Scrima, 191-210.

${ }^{18}$ Marco Toti, "Religious Morphology, Hermeneutics and Initiation in Andrei Scrima' Il padre spirituale (The Spiritual Father)," Aries. Journal for the Study of Western Esotericism 11, no. 1 (2011): 77-97; "Morfologia religiosa ed ermeneutica ne «Il padre spirituale» di A. Scrima," in Dumbravă, Tătaru-Cazaban, André Scrima, 159-73.

${ }^{19}$ André Scrima, Il padre spirituale, a cura di Adalberto Mainardi (Magnano: Edizioni Qiqajon, 2000).
} 
In L'avènement philocalique, André Scrima presents the prayer of the heart or Hesychast spirituality as part of the Church tradition, which is inextricably linked to the Orthodox liturgy and the "inheritance" of the Church Fathers or - this is the essential nuance - as interiority or the tradition. The image he chooses to illustrate this relationship derives from Saint Gregory Palamas's texts: "The heart is the innermost body of the body". In other words, the prayer of the heart is the core of tradition, the innermost tradition of the Eastern Church, "the path of contemplative life". ${ }^{20}$ However, is "the Hesychast tradition a secret-based tradition?" This question clearly shows the angle from which Scrima approaches his theme in order to subsequently detach himself "from the various esoteric interpretations (...) unable to bring the understanding of Hesychast spirituality to authentic light". ${ }^{21}$ The only merit of traditionalist esotericism acknowledged by the young Scrima was that of having maintained "a general effervescence of ideas". ${ }^{22}$ In other words, it performed a heuristic function, but its approach fails to grasp the essence of the phenomenon. For Scrima, embracing the contemplative path of prayer means a personal actualization of an experience of the Holy Spirit which establishes itself as tradition throughout history and becomes accessible under specific circumstances that keep its mystery alive in certain timely moments as well:

La vie spirituelle a été toujours conçue dans l'Église orientale comme une transmission vivante, une parádosis, véhiculant l'Esprit incarné dans l'histoire. Pour évident que cela soit, il n'y a ici aucune place toutefois pour un conflit d'importance avec la Tradition de l'Église tout court, ni pour une distinction de nature d'avec celle-ci. C'est le souffle du même Esprit-Saint qui allume le feu de la prière du cœur et le garde brûlant dans l'Église ; dans une position d'intériorité, mais qui, précisément à cause de cela, ne permet aucune dépréciation ésotérique de la vie spirituelle réalisée sous d'autres formes. ${ }^{23}$

Therefore, "initiation" or "blessing" is necessary (Scrima prefers the latter technical term, "blessing", which points to logos and individualises the type of Hesychast initiation, differentiating it from external initiation structures), "the elements of the Hesychast secret" being the following: subtle teaching, the transmission of a spiritual filiation, discretion and humbleness (defined

\footnotetext{
${ }^{20}$ Scrima, "L'avènement," 447.

${ }^{21}$ Ibidem, 446 (author's translation). For more penetrating annotations on the "gnostic" spiritual perspective, see: "Note la o antropologie eventuală," 201, 214.

${ }^{22}$ Ibidem.

${ }^{23}$ Ibidem, 300.
} 
as a "metaphysical state"). Here Scrima enters in an open polemic with the esoteric understanding of initiation and the "esoteric truth". ${ }^{24}$ His study stirred up the traditionalists' interest, most notably that of Michel Vâlsan, the en titre disciple of Guénon, who attempted to decrypt it from a Guenonian perspective and to provide an answer to Scrima's critical delimitations. ${ }^{25}$

After 36 years, having returned to Bucharest, André Scrima wrote a preface to the Romanian translation of Schuon's book, De l'unité transcendante des religions. He makes a long excursus on the context in which the book was published after the devastating Second World War, a context of discovery of the "other" by the West: also "exotic" in its own right, Orthodoxy began to be known only after the West had studied the Oriental religions and, in Scrima's view, their projection was still hovering over the reception of the Eastern spiritual tradition. ${ }^{26}$ When the West rediscovered the existence of Hesychasm, "the vision and living experience of the Holy Tradition of the Church" ${ }^{27}$ was celebrated at Antim, where Schuon was widely read. Apart from this clear testimony usually framed as reflection on the meanings of history from a spiritual perspective, Scrima admits that "the transcendent unity of religions" is "a felicitous phrase", an intuition in "the horizon opened by René Guénon". ${ }^{28}$ His Preface contains two important reflections: one is related to the meaning of transcendence as "non-abstract essentiality", "a kind of core" of reality, "a matrix of an energy irreducible to the world", ${ }^{29}$ whereas the other is related to the critique of Schuon's view on the incarnation of the Logos and Christ's sacrifice, which involves a recurrent Platonic temptation, as well as "a too natural" exigency "of immanent logic". ${ }^{30}$ Here the crux of the matter is represented by the inability to understand the kenosis, the ultimate humbleness of the Logos. However, Scrima considers the reading of Schuon's book as an opportunity to further explore the tension between the perspective of transcendence as an "accomplished unity" and the realm of concrete, fragmented humanity, where the "common" place of transcendence becomes a "proper" one: "We claim its exclusive property, where the other can have access only if the other accepts to transform into myself..$^{31}$

\footnotetext{
${ }^{24}$ Ibidem, 448.

25 This matter has been thoroughly examined by Enrico Montanari, along with Vâlsan's correspondence with Anton Dumitriu, see: Montanari, La fatica, 83-179.

${ }^{26}$ Scrima, "Cuvînt înainte," in Teme, 154-55.

${ }^{27}$ Ibidem, 157.

${ }^{28}$ Ibidem, 147.

${ }^{29}$ Ibidem, 150.

${ }^{30}$ Ibidem, 155-56.

${ }^{31}$ Ibidem, 148-49 (author's translation).
} 
Scrima's critical rereading of Schuon's book reveals three "risks" regarding the attitude towards religious diversity and its "transcendent unity": excessive familiarity with one's own tradition which ignores the other; the idolization of the Living God at conceptual level; and the fanatic refusal of the other. ${ }^{32}$ As a counterpoint, he insists on understanding "transcendence" as "the living universal" accessible by experience in the realm of the Holy Spirit.

Two years later, in Timpul Rugului Aprins, he acknowledges the role played by Guénon in calling attention to the "initiation structure" of spiritual life, highlighting the contemporaneous facts as a "significant coincidence": the publication of Guénon's works in the West and the appearance of John the Stranger at Antim in order to transmit "the knowledge and the living prayer of the heart" to the disciples he had appointed, "a mysterious form or hypostasis meant to ensure the advancement on the spiritual path (...) only through blessing". ${ }^{33}$ Of all remarks made by André Scrima, two are of paramount importance at this point: 1. "the problem of initiatic transmission" formulated by Guénon has been "distorted" by others; 2 . the mystery of initiation does not depend on "interdiction", but on the refined, sound, discrete knowledge one has access to through blessing. We find here the invariable ideas posited in L'avenement philocalique, which are developed in a revealing chapter on "the guardians of the Inheritance" or of Tradition (parádosis)..$^{34}$ Once again, coming back to the meaning of tradition, Scrima lays emphasis on the fact that this is not tantamount to a visible, quantitative, measurable "translation", but to an "unmediated transmission of the knowledge and the living prayer of the mind from master to disciple", which requires a "vertical, zenithal" communication through "the invisible". ${ }^{35}$ To put it differently, spiritual paternity, which is exerted through blessing, and thus opens the gate of prayer, is actually a vivid, concrete expression of divine paternity which, all by itself, can "give birth" to spiritual sons and can offer the experience of knowing God beyond time. According to Scrima's hermeneutics, the transmission of the Holy Spirit that Christ fulfilled on the cross (the verb employed by the evangelist is parédoken ${ }^{36}$ ) constitutes the Christian tradition and continues to manifest itself within it in a mysterious way.

Monks are the "guardians of Tradition": though the call to a contemplative life is not the exclusive preserve of the monks, they choose the

\footnotetext{
${ }^{32}$ Ibidem, 151-53.

${ }^{33}$ Scrima, Timpul, 49.

${ }^{34}$ Scrima, L'Évangile de Jean. Un commentaire, traduction de Marcel Pirard et Anca Vasiliu, introduction par Anca Vasiliu (Paris: Cerf, 2017), 363-64.

${ }^{35}$ Idem, Timpul, 50, 51 (author's translation).

${ }^{36}$ Ibidem, 42, 52.
} 
condition of the stranger, of the pilgrim, of an insignificant human appearance which, by its very nature, makes them transparent and able to transmit what they received. At this point Scrima makes a digression when he labels the "guardians of Tradition" as "hassassins", thus pointing to an Ismaelite mystical sect, as well as to Yves Ponsoye's book, L'Islam et le Graal (1974), which quotes Guénon, for whom the "hassassins" appear as "guardians of the Holy Land" (which meant not only the visible Holy Land, but also, in Scrima's words, "a kind of imaginal continent where all those who were knights in the ritualistic sense of the word used to meet" ${ }^{37}$ ). In his minute analysis of Guenonian reminiscences in Scrima's texts, Enrico Montanari identified a passage taken from Le symbolisme de la croix, which Scrima uses to interpret "blessing" as Christian initiation, without mentioning Guénon at all. ${ }^{38}$ Also, Montanari discovered allusions to Guenonian themes related to "initiation centres", the tension between the modern world and the world of tradition which leaves only "traces" behind, etc. It is true that Scrima evoked John the Stranger as if the latter had known "the underground cartography of tradition". ${ }^{39}$ Nonetheless, it is difficult to say whether the allusions to Guénon are strictly related to the language used, rather than to the same vision. In Timpul Rugului Aprins the passages describing the hesychast "initiation" (with reference to Guénon and Schuon) and the comparisons with other religious traditions, especially with Islam, appear as hermeneutical exercises based on analogical thinking in order to define a "morphology" of spiritual experience. ${ }^{40}$ But Scrima is not, even when he borrows without attribution from Guénon, a "perennialist", neither is the analogy he developed between "blessing" and "baptism" a formula of a special, quasi-sacramental "initiation". ${ }^{41}$

A comparative analysis of the published texts on tradition and Hesychasm points out two invariable aspects of his hermeneutics: 1 . tradition is a transmission of living knowledge and of the access to an experience of the Living God through his Holy Spirit; it is not only a "repository" of the experience of faith, but also a source of renewal, dynamism, and revelation; 2. Hesychasm is not an "universalizable" spiritual tradition without Christ, who remains its centre; this Christocentrism, balanced by a pneumatological approach, is always accompanied by the warning - which also comes from

\footnotetext{
${ }^{37}$ Ibidem, 50, n. 17.

${ }^{38}$ Montanari, La fatica, 138.

${ }^{39}$ Scrima, Timpul, p. 88. See also: Montanari, La fatica, 142-43; Toti, "Religious Morphology," 88.

${ }^{40}$ See also: Toti, "Religious Morphology," 92.

${ }^{41}$ Scrima, Timpul, 57-58.
} 
Greek patristics - that we should not try to "lock up" God in our categories (the danger of conceptual idolatry). ${ }^{42}$ As for the traditionalist perspective, it is true that Scrima gradually becomes explicit, at least from the point of view of the acknowledgement of the role that the reading of Guénon and Schuon initially had on some of the participants in "the philokalic revival" at Antim Monastery. First of all, I think that what Scrima conveyed to us was a historical testimony: Guénon and Schuon were read in Orthodox milieus and were able to draw attention to some aspects of the Orthodox tradition that had fallen into oblivion. ${ }^{43}$ They had an inchoative function of intellectual stimulation, which had to be overcome because - according to Scrima - Traditionalism did not possess, or could not grant access through an unmediated religious experience, to what is alive, to the "living universality" of Christianity. It is precisely the blessing transmitted by John the Stranger that played this role.

However, throughout decades of ecumenical and inter-religious commitment, André Scrima gradually integrated his Neo-patristic reflections from the 50's, which echo both the philokalic line of theologian Dumitru Stăniloae ${ }^{44}$ and of other Orthodox theologians from the West, into the space of a "theology of religious pluralism" 45 , in which his detachment from Traditionalism appears evident. He was one of the few Orthodox theologians who passed beyond the inter-Christian dialogue to boldly step into a territory where the firm landmarks of tradition are even fewer and weaker. In this case too, he starts from the experience of the Holy Spirit, which is the core of the Hesychast tradition, and from the calling to discern "the signs of the times", which this experience makes possible in order to approach the potential encounter of religions as transcendent "convergence", beyond any "facile

\footnotetext{
${ }^{42}$ Scrima, "La tradition du père spirituel dans l'Église d'Orient," Hermès 4 (1966-1967): 79_ 94; nouvelle série 3 (1983): 173-89; "The Hesychastic Tradition: An Orthodox-Christian Way of Contemplation," in Contemplation and Action in World Religions. A Rothko Chapel Book, 1977-1978, 136-50; "Philocalie et prière du coeur," Connaissance des religions, numéro hors-série: Roumanie, terre de foi (avril 1990): 92-118. See: Ioan-Alexandru Tofan, André Scrima și fizionomia experienței spirituale (București: Humanitas, 2019).

${ }^{43}$ Scrima, Timpul, 56-57.

${ }^{4}$ See: idem, Antropologie apofatică, ed. Alexandrescu (București: Humanitas, 2008), 15-170.

${ }^{45}$ See particularly: Manolescu, Europa și întâlnirea religiilor. Despre pluralismul religios contemporan (Iași: Polirom, 2005), 169-98; Dumbravă, " "Rivelazione e religioni» secondo Andrei Scrima," in Quaderni di Studi e Materiali di Storia delle Religioni Supplemento 18 - La Storia delle religioni e la sfida dei pluralismi, a cura di S. Botta, M. Ferrara, A. Saggioro, 2017, 568-80. For a diachronic perspective on Scrima's approach to religious plurality, see: Valentin Cioveie, "Teologia religiilor necreștine - abordarea răsăriteană. Hermeneutica Părintelui Andrei Scrima,” in Tabor 11, no. 1 (Ianuarie 2017): 83-95; no. 2 (Februarie 2017): 91-103.
} 
concord" or syncretism. ${ }^{46}$ The interventions he had in the margins of a talk given by the French theologian Joseph Moingt ("Le Christ et les religions non-chrétiennes" and "Religions de salut et salut en Jésus-Christ", Beirut, $1985)^{47}$, the lectures on Christianity and Islam delivered at the universities of Lebanon ${ }^{48}$ or his reflections about the universal meaning of Jerusalem are particularly relevant for this dimension of his thinking. ${ }^{49}$

Scrima's approach does not aim to outline a secret, an original tradition throughout the religious history of mankind, but to indicate a mutual discovery, a meeting with religious otherness so that the other should not be a projection of one's prejudices and the object of the discovery should not be "the same thing, but the Same in a different way" ${ }^{0}$ : "If there is a real sense of the meeting of religions, he said in one of his lectures, it certainly is not related to elaborating a discourse about God, but to discovering each other and together in Him". ${ }^{51}$ Thus, in the horizon of the Holy Spirit he frequently invoked, Scrima tried to practice "a kind of theological communication both with the doctrine and the living experience of the other great spiritual traditions", including those that lie outside of "the monotheist domain", a "centred openness", 52 being aware of the freedom of "the living God from the forms of temporal expression that He Himself can confirm, though $\mathrm{He}$ is not captive to them". ${ }^{33}$

Maybe this is the reason why Scrima was still fond of the expression he had discovered in his youth: "the transcendent unity of religions", which he understood as a discovery of "qualitative universality that "religion" preserves within its own being" 54 precisely due to the apophatic perspective on transcendence, which denies conceptual idolatry and allows for its "traces"

\footnotetext{
${ }^{46}$ Scrima, Teme, 101.

${ }^{47}$ Published for the first time in Romanian translation by Manolescu: Scrima, Teme, 73-103.

${ }^{48}$ Dumbravă, "Theology and History of Religions in the Middle East. A Brief Account: «Fr. André Scrima, spiritual and peace mediator in Libanon (1970-1980)»," in Proceedings of the 9th EASR Conference, Biblioteca dell'Officina di Studi Medievali 16.1/2, Palermo 2013, 597-610.

${ }^{49}$ Scrima, "Jérusalem, cité «unique et universelle» pour les religions monothéistes," Concilium 155 (1980): 117-29 (the long unpublished version was translated in Teme, 29-72). See also: Claude Geffré, "Jérusalem comme ville sainte pour les trois monothéismes dans la pensée et la spiritualité d'André Scrima," in Dumbravă, Tătaru-Cazaban, André Scrima, 141-48.

${ }^{50}$ Scrima, Teme.

51 Ibidem, 94 (author's translation).

52 Scrima and Andrei Pleșu, "Un «test de la capăt» al faptului religios," Dilema 331 (11-17 juin 1999); 333 (25-31 juin 1999): 8-9, 11, in Scrima, Teme, 121.

53 Scrima, Teme, 91.

${ }^{54}$ Ibidem, 120.
} 
to be intuited in all religious traditions, particularly in a time when the Holy Spirit was sent to "discover the entire truth". In a dialogue with Professor Andrei Pleșu (1993), Scrima found such a formula, which synthesized all his quests for a spiritual hospitality in an eschatological perspective ${ }^{55}$ : "It is not religions that are one and the same in the eyes of God, but the living man who experiences them, man in a state of belief. (...) For all eternity, in front of God we are the same in a different way" 56 .

\footnotetext{
${ }^{55}$ On Scrima's "hermeneutics of hospitality," see: Manolescu, "André Scrima și sensul metafizic al ospitalității," in André Scrima. O gândire fără țărmuri. Ecumenism și globalizare (București: Humanitas, 2005), 35-54; "André Scrima: herméneute de la convergence des religions," L'Orient des Dieux. Revue du Département des Sciences des Religions 6-7 (20062007): 83-102. I do think that the relation between hospitality and eschatology, underlined by Anca Manolescu, represents a valuable key to Scrima's religious hermeneutics.

${ }^{56}$ Scrima, Teme, 122 (author's translation).
} 